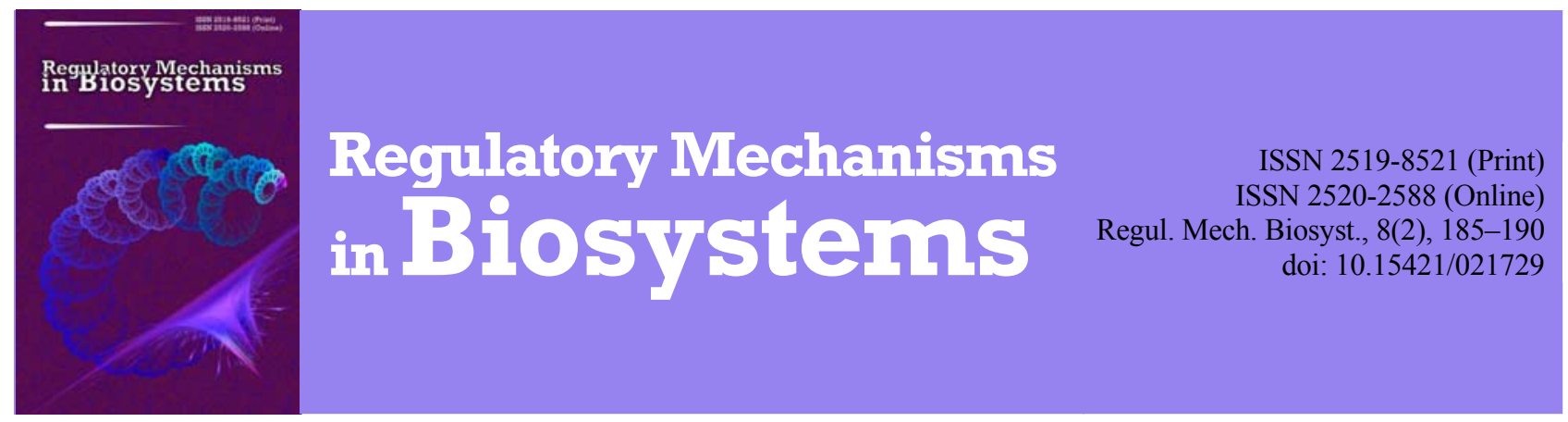

\title{
The effect of biologically active feed additives of humilid substances on the antioxidant system in liver mitochondria of gerbils
}

\author{
O. O. Dyomshina*, G. O. Ushakova*, L. M. Stepchenko** \\ * Oles Honchar Dnipro National University, Dnipro, Ukraine \\ **Dnipro State Agrarian-Economic University, Dnipro, Ukraine
}

Article info

Received 29.03.2017

Received in revised form 24.04.2017

Accepted 28.04.2017

Oles Honchar Dnipro National University, Gagarin Ave., 72, Dnipro, 49010, Ukraine. Tel.: +38-050-607-52-83. E-mail:olga-d2009@ukr.net

Dnipro State

Agrarian-Economic University, Sergey Efremov Str., 25 , Dnipro, 49600, Ukraine.
Dyomshina, O. O., Ushakova, G. O., \& Stepchenko, L. M. (2017). The effect of biologically active feed additives of humilid substances on the antioxidant system in liver mitochondria of gerbils. Regulatory Mechanisms in Biosystems, 8(2), 185-190. doi:10.15421/021729

Mitochondria are organelles that are most sensitive to the action of stressors on any cell of the entire organism and exposure to chemicals which can cause its dysfunction and cell death in general. Especially sensitive to adverse conditions are liver mitochondria, where the processes of biotransformation of endogenous and exogenous metabolites are formed, not only in the liver, but also in other organs and tissues. Mitochondrial dysfunction can cause instant hepatic cytolysis and steatosis. Therefore, early detection of mitochondrial toxicity is important during preclinical studies of new pharmacological agents, as this will help avoid remote negative effects. The biologically active feed additive Humilid, a complex of humic acids known for their antidiarrheal, analgesic, immune-stimulating, and antimicrobial properties; shows a corrective effect on the activity of the lysosomal cathepsin; enhances the positive effect of hematopoiesis on hemoglobin and its quality indicators consisting of red blood cells; and activates the synthesis and accumulation of fibronectin expression that takes part in the formation of immunological protection of animals. The objective of our experiment was to determine the effect of complex biologically active feed additives based on humic substances on the biochemical indicators of the liver mitochondrial antioxidant system of Mongolian gerbils (Meriones unguiculatus Milne-Edwards, 1867). The experiment was conducted on mature (6 months) Mongolian gerbils. The data obtained showing the influence of the biologically active feed additives Humilid, alone or in combination with ascorbate and Eco-impulse Animal, on the antioxidant defense system of liver mitochondria of gerbils are presented in this article. The proven antioxidant effect of humic substances in the mitochondrial fraction of the liver which inhibits the accumulation of oxidized products in the cells is shown, confirmed by the decrease in the number of TBA-active products, catalase activation, and an increase in the concentration of cytochrome C. Also, an increase in the amount of cytochrome $\mathrm{C}$, which is a direct participant in the mitochondrial respiratory chain and provides efficient electron transport, indicates the acceleration of energy supply processes. The functional activity of mitochondria was accompanied by increased activity of aspartate aminotransferase involved in the shuttle of malateaspartate transport of electrons through the mitochondrial membrane. The results obtained indicate the positive reaction of gerbil liver mitochondria under the influence of the biologically active feed additives of humic substance.

Keywords: Humilid; ascorbic acid; Eco-impulse Animal; aspartate aminotransferase; catalase; superoxide dismutase; TBA-active products; cytochrome C

\section{Вплив біологічно активних кормових добавок гумінової природи на систему антиоксидантного захисту мітохондрій печінки монгольської піщанки}

\author{
О. О. Дьомшина*, Г. О. Ушакова*, Л. М. Степченко** \\ *Дніпровський національний університет імені Олеся Гончара, Дніпро, Україна \\ **Дніпровський державний аграрно-економічний університет, Дніпро, Украӥна
}

Наведено дані щодо оцінки впливу біологічно активної кормової добавки Гумілід окремо та в суміші з аскорбіновою кислотою, або «Еко-імпульс Animal» на систему антиоксидантного захисту мітохондрій печінки піщанок. Доведено антиоксидантний вплив гумінових речовин у мітохондріях печінки, що підтверджено зниженням кількості ТБК-активних продуктів, активізацією каталази та підвищенням концентрації цитохрому С. Збільшення кількості цитохрому С свідчить про прискорення процесів енергозабезпечення за рахунок активації дихального ланцюга мітохондрій та ефективного транспорту електронів. Визначено потенціювальний синергізм аскорбінової кислоти та Гуміліду, що посилює антиоксидантні властивості гумінових речовин. Функціональна активність мітохондрій супроводжувалась підвищенням активності аспартатамінотрансферази, яка бере участь у малатаспартатному човниковому транспорті електронів крізь мітохондріальну мембрану та циклі сечовини. Встановлено сильний прямий корелятивний зв'язок високого ступеня значимості між 
кількістю ТБК-активних продуктів і активністю каталази, кількістю ТБК-активних продуктів та кількістю цитохрому С в умовах застосування Гуміліду в суміші з аскорбіновою кислотою, а також вірогідний сильний обернений зв'язок високого ступеня значимості між кількістю ТБК-активних продуктів та активністю каталази, активністю СОД та кількістю цитохрому С за впливу біологічно активної добавки «Еко-імпульс Animal». Отримані результати вказують на позитивну реакцію мітохондрій печінки піщанок за впливу біологічно активних кормових добавок гумінової природи.

Ключові слова: Гумілід; аскорбінова кислота; «Еко-імпульс Animal»; аспартатамінотрансфераза; каталаза; супероксиддисмутаза; ТБКактивні продукти; цитохром С

\section{Вступ}

Органела, яка бере активну участь у більшості катаболічних процесів і забезпечує клітини енергією, - це мітохондрія. Саме мітохондрія найчутливіша органела до дії стресових факторів будь-якої клітини цілісного організму. Вплив хімічних речовин на мітохондрії може викликати їх дисфункції та бути причиною загибелі клітини в цілому (Begriche et al., 2011; Brinkmann et al., 2013; Buron et al., 2017). Особливо чутливі до несприятливих умов серед клітинних органел мітохондрії печінки, де відбуваються процеси біотрансформації ендогенних і екзогенних метаболітів, які утворюються не тільки у печінці, а і в інших органах і тканинах (Gergalova and Skok, 2011; Melnichuk et al., 2013; Hamdallah et al., 2014). Порушення функцій мітохондрій може бути причиною миттєвого печінкового цитолізу та стеатозу (Dykens et al., 2007; Labbe et al., 2008; Vadzuk et al., 2010). Тому ранне виявлення мітохондріальної інтоксикації важливе під час преклінічних досліджень нових фармакологічних препаратів, оскільки це допоможе уникнути віддалених негативних наслідків (Hynes et al., 2013; Felser et al., 2014; Buron et al., 2017).

Мітохондрії - джерело вільних радикалів, які у значній кількості утворюються внаслідок розвитку патологій різної етіології, що зумовлює підвищення продукції $\mathrm{H}_{2} \mathrm{O}_{2}$ i $\mathrm{H}_{2} \mathrm{O}_{2}$-індукованої інактивації аконітази за загального зниження концентрації каталази, що спричинить передчасне старіння клітини (Dai et al., 2017). Системи, які знешкоджують надлишкову кількість токсичних окиснених метаболітів, - високомолекулярна та низькомолекулярна антиоксидантні системи, які функціонують одночасно. Супероксиданіон - один із токсичних оксигенових метаболітів, що інтенсивно утворюється в дихальному ланцюзі мітохондрій. Ензими, які знешкоджують супероксиданіон - це супероксиддисмутаза (СОД) та цитохром C, найвищі рівні яких реєструються саме в мітохондріях печінки (Demin et al., 2008; Donghong et al., 2015; Serova et al., 2016).

У печінці форма СОД, що домінує та складає понад 65\% загальної активності - мітохондріальна (Mn-COД) (Surai and Fisinin, 2013). Цитохром C, а саме його окиснена форма $\left(\mathrm{Fe}^{3+}\right)$, виявляє потужні антиоксидантні властивості за рахунок ефективнішого, ніж СОД, окиснення супероксиданіона в молекулярний оксиген (Demin et al., 2008; Serova et al., 2016), тому вважається одним із маркерів ефективності функціонування антиоксидантної системи. Крім цього, іiї використовують як маркер оксидативного стресу (Birk et al., 2014). Зростання його концентрації у цитозольній фракції клітини свідчить про підвищення проникності зовнішньої мітохондріальної мембрани (як наслідок активації окисних процесів), що запускає механізм загибелі клітини шляхом апоптозу.

Окисне пошкодження також впливає на реплікацію та транскрипцію мітохондріальної ДНК і спричиняє зниження мітохондріальної функції, яка, у свою чергу, зумовлює збільшення рівня активних форм оксигену та подальше пошкодження мітохондріальної ДНК (Cui et al., 2012). Пошкодження мітохондріальних макромолекул клітинного дихання токсичними формами оксигену, у свою чергу, витупає причиною передчасного старіння клітин і організму в цілому (Lapointe, 2014; Lapointe et al., 2014). Запобігає оксидації клітини їі антиоксидантна система - важлива ланка функціонування в нормі, особливо за впливу екзогенних факторів.

Біологічно активна кормова добавка Гумілід (ТУ У 15.700493675 004:2009) - це комплекс гумінових кислот, відомих своїми антидіарейними, знеболювальними, імуностимулювальними та антимікробними властивостями, здатністю впливати на конверсію корму, ріст і якість м'яса сільськогосподарських тварин (Stepchenko and Skorik, 2006; Kovalenko et al., 2010; Stepchenko, 2010). Гідрогумат проявляе корегувальний ефект на активність лізосомальних катепсинів, що може бути спричинене його мембранотропними властивостями та активацією внутрішньолізосомального протеолізу (Stepchenko, 2010), тобто впливає на молекулярні механізми адаптації тварин за дії хронічного стресу. Суміш сфагніну й дубліну викликає посилення гемопоезу, позитивно впливає на вміст гемоглобіну та його якісні показники у складі еритроцитів (Stepchenko and Skorik, 2006; Shvetsova et al., 2010). Ці біологічно активні кормові добавки зумовлюють зростання синтезу, експресії та накопичення фібронектину, який бере участь у формуванні імунологічного захисту тварин (Stepchenko, 2010), знижують кардіотоксичність високих доз адреналіну, що зумовлено їх здатністю зв'язувати вільні радикали (Paronik et al., 2015). Також у дослідженнях на пухлинах печінки (Pan et al., 2016) препарат Mineral Pitch, що містить фульвокислоти та гумінові кислоти, виявив себе як потенційний антипроліферативний та проапоптотичний агент через утворення перекисних продуктів i NO, а також шляхом модуляції рівня експресії miRNA-21 i miRNA-22, що дало авторам можливість рекомендувати використовувати цей препарат як дієтичну добавку, яка може знизити ризик розвитку раку та пригнічувати ріст пухлини.

Фульвокислоти та гумінові кислоти - джерело мікро- та макроелементів i, одночасно, активатори підвищення їх конщентрації в органах і тканинах (Szabo et al., 2017). У дослідженнях Ryzhkovskaia et al. (2014) показано, що споживання щурами 3 парацетамольним експериментальним гепатитом мінеральної води, яка містить гумінові кислоти, протягом 21 доби зумовило модифікацію ультраструктури гепатоцитів. Спостерігали збільшення кількості цистерн гранулярного ендоплазматичного гетикулуму, гранул глікогену та мітохондріальний поліморфізм. Відбувалось відновлення енергетичних процесів, глікоген- і протеїнсинтезувальних функцій, порушених у результаті введення парацетамолу. Фаза після відміни лікувальних препаратів (14 діб) характеризувалася подальшим зміцненням репаративних процесів і функціональної активності клітин печінки. Гуміліди використовують у профілактиці та терапевтичних заходах у ветеринарній практиці для всіх видів тварин (ЕМЕА, 1999).

«Еко-імпульс Animal» - біологічно активна кормова добавка, яка являє собою комплексний препарат, одержаний шляхом лужного гідролізу торфу за впливу електричного струму. Використовують у складі раціону сільськогосподарських тварин та птиці з метою поліпшення функціонального стану організму, підвищення імунітету, профілактики стресу, а також підвищення продуктивності та інтенсивності росту.

Незважаючи на широке використання біологічно активних кормових добавок на основі гумінових речовин у ветеринарії, птахівництві, тваринництві та рослинництві, дослідження їх впливу на організм людини $з$ метою подальшого впровадження у медичну практику ще тривають. Відомості про вплив досліджуваних препаратів на антиоксидантну систему мітохондрій печінки ссавців відсутні. Класичний антиоксидант - аскорбінова кислота найважливіший і найефективніший низькомолекулярний компонент антиоксидантної системи кожної клітини, але їі комбінований вплив із гуміновими речовинами поки не досліджено.

Мета цієї статті - визначити вплив комплексних біологічно активних кормових добавок на основі гумінових речовин Гумі- 
лід окремо або у комплексі з аскорбіновою кислотою, або «Еко-імпульс Animal» на стан антиоксидантної системи мітохондрій печінки монгольської піщанки.

\section{Матеріал і методи досліджень}

Експеримент проведено на монгольських піщанках (Mongolian gerbilia, Meriones unguiculatus Milne-Edwards, 1867) зpiлого віку (6 місяців) середньою вагою 63-83 г, яких утримували у стандартних умовах віварію. Маніпуляції з тваринами проводили відповідно до правил «Європейської конвенції захисту хребетних тварин, які використовуються для експериментальних та інших наукових цілей» (Страсбург, 1986). Методика проаналізована та схвалена локальним етичним комітетом ДНУ.

Дослідні біологічно активні кормові добавки додавали до питної води у розрахунку 5 мг/кг ваги тварини. Тварин поділили на чотири дослідні групи по 6 особин у кожній: I група інтактні тварини (контроль), які отримували звичайний раціон; II - тварини, яким у питну воду додавали $1 \%$ розчин Гуміліду (отримано та апробовано у проблемній лабораторії з гумінових речовин ім. Л. А. Христєвої, ДДАЕУ); ІІІ - у питну воду додавали суміш $1 \%$ розчинів Гуміліду та аскорбінової кислоти (ПрАТ «Фармацевтична фірма "Дарниця"», Київ, Україна); IV у питну воду додавали $1 \%$ розчин препарату «Еко-Імпульс Animal» (ДДАЕУ). Експеримент проводили протягом 24 діб. Наприкінці тварин зважували та виводили 3 експерименту під етерним наркозом, видаляли печінку, промивали іï у фізіологічному розчині та використовували для подальших досліджень.

Гомогенат печінки та іiі мітохондріальну фракцію отримували шляхом диференційного центрифугування у градієнті сахарози методом Wieckowski et al. (2009). Визначення загальної кількості протеїну та активності аспартатамінотрансферази (AcАТ, КФ 2.6.1.1) проводили з використанням стандартних лабораторних тест-наборів (Фелісіт, Дніпро, Україна) за методами Burtis et al. (2012) та Young (2014) згідно з протоколом фірми виробника. Активність каталази (КТ, КФ 1.11.1.6) визначали за здатністю пероксиду водню утворювати із солями молібдену стійкий забарвлений комплекс (Koroluk et al., 1988). Активність каталази виражали в мккат./кг мітохондріальної фракції. Активність супероксиддисмутази (СОД, КФ 1.15.1.1) оцінювали як здатність ензиму інгібувати реакцію окиснення кверцетину (Kostuk et al., 1990). Активність СОД виражали в умовних одиницях (у. о.). За умовну одиницю приймали активність ензиму, який здатний викликати інгібування кверцетину на 50\% у розрахунку на 1 мг протеїнів тканини. Кількість ТБК-активних продуктів визначали фотометрично за концентрацією забарвленого комплексу (Andreeva et al., 1988), який утворювався за реакції малонового діальдегіду (МДА) у кислому середовищі із двома молекулами тіобарбітурової кислоти (ТБК). Кількість МДА виражали у мікромолях ТБК-активних продуктів на 1 мг протеїну мітохондріальної фракції. Кількість цитохрому $\mathrm{C}$ - за його здатністю відновлювати дитіонат натрію (Selivanov et al., 1997).

Статистичний аналіз результатів проводили методом ANOVA. Вірогідними вважали відмінності на рівні $\mathrm{P}<0,05$.

\section{Результати}

Обсяг загального пулу протеїнів у біологічних рідинах, тканинах і їх компартментах - один із найважливіших показників метаболізму. Дослідження загального вмісту протеїнів у отриманих мітохондріальних фракціях піщанок показали наявність стабільного пулу протеїнів за умов застосування гумінових препаратів протягом 24 діб у визначеній дозі (рис. 1).

Загальна кількість протеїнів у мітохондріальній фракції тварин, яких випоювали Гумілідом як окремо, так і у суміші 3 аскорбіновою кислотою, була майже на рівні контрольної групи. У тварин, яких випоювали «Еко-імпульс Animal», кількість протеїнів знижувалась вірогідно на 27\% порівняно 3 контрольною групою та іншими дослідними групами.

Оцінювання ензиматичної активності аспартатамінотрансферази в мітохондріальних фракціях, отриманих із печінки дослідних тварин, показало несуттєве підвищення (в 1,2 раза) активності цього ензиму за впливу Гуміліду (рис. 2). У тварин, яким у питну воду додавали суміш Гуміліду та аскорбінової кислоти або «Еко-імпульс Animal», активність АсАТ підвищувалась у 2,5 раза порівняно з контрольною групою.

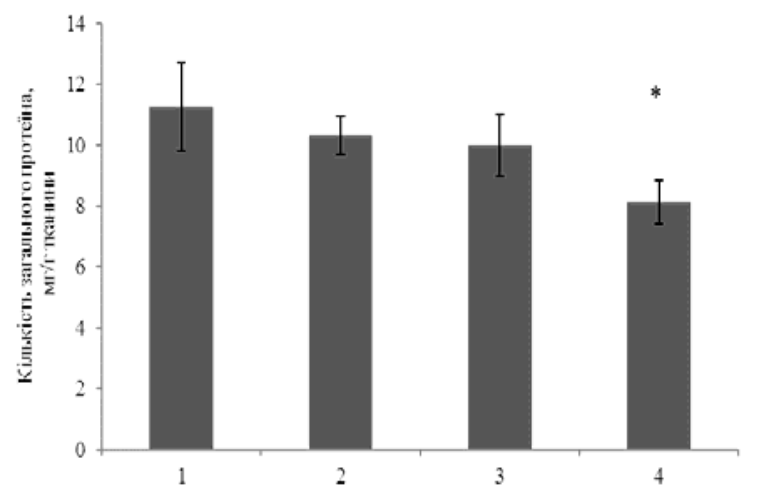

Рис. 1. Загальна кількість протеїнів у мітохондріальній фракції печінки піщанок: 1 - контрольна група тварин, 2 - тварини, які отримували у питній воді $1 \%$ Гуміліду, 3 - у питній воді суміш $1 \%$ Гуміліду та $1 \%$ аскорбінової кислоти, 4 - у питній воді $1 \%$ препарату «Еко-імпульс Animal»; * $-\mathrm{P}<0,05$ відносно контрольної групи; $\mathrm{x} \pm \mathrm{SD}, \mathrm{n}=6$

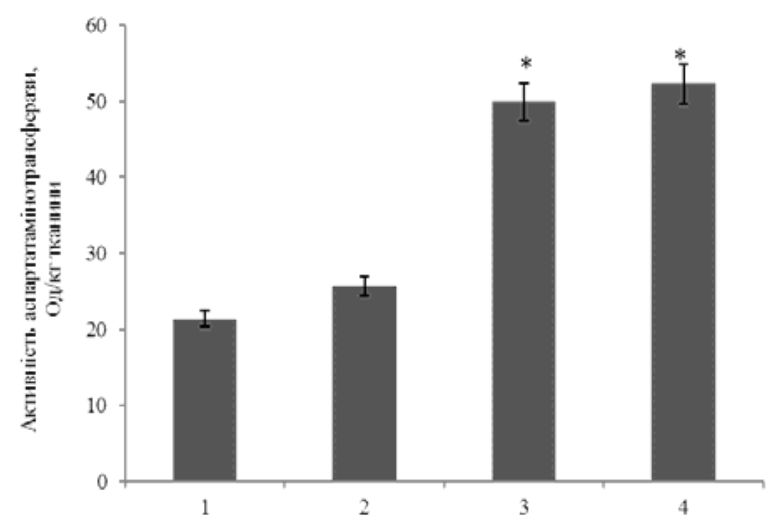

Pис. 2. Активність аспартатамінотрансферази в мітохондріальній фракції печінки піщанок: назви груп див. рис. 1

Для встановлення здатності препаратів гумінових кислот виявляти антиоксидантні властивості в мітоходріальних фракціях печінки визначали кількість ТБК-активних сполук, активність каталази та супероксиддисмутази - маркерів ступеня оксидативного стресу та стану антиоксидантної системи. Кількість ТБК-активних сполук суттєво зменшується в мітохондріальній фракції печінки в усіх дослідних групах тварин у 1,52,0 раза відносно контрольної групи (рис. 3). Активність каталази у досліджуваних фракціях печінки піщанок зросла на $11 \%$ тільки у випадку впливу Гуміліду (рис. 4), тоді як в інших групах перебувала на рівні контрольної групи.

Зміну активності супероксиддисмутази (СОД) у мітохондріальній фракції печінки спостерігали тільки у групі тварин, яких випоювали препаратом «Еко-імпульс Animal»: спостерігали зниження активності на 40\% порівняно 3 контрольною групою тварин (рис. 5).

Для визначення енергозабезпечення печінки та цілісності мітохондріальної мембрани за застосування ксенобіотиків на основі гумінових речовин визначали кількість цитохрому С у мітохондріальній і водорозчинній фракціях печінки, основна частина якої представлена цитозольними протеїнами (рис. 6). 


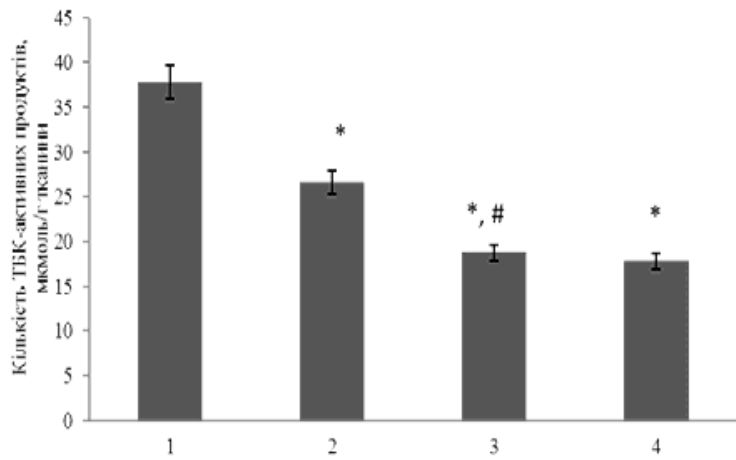

Рис. 3. Кількість ТБК-активних продуктів у мітохондріальній фракції печінки піщанок: назви груп див. рис. 1

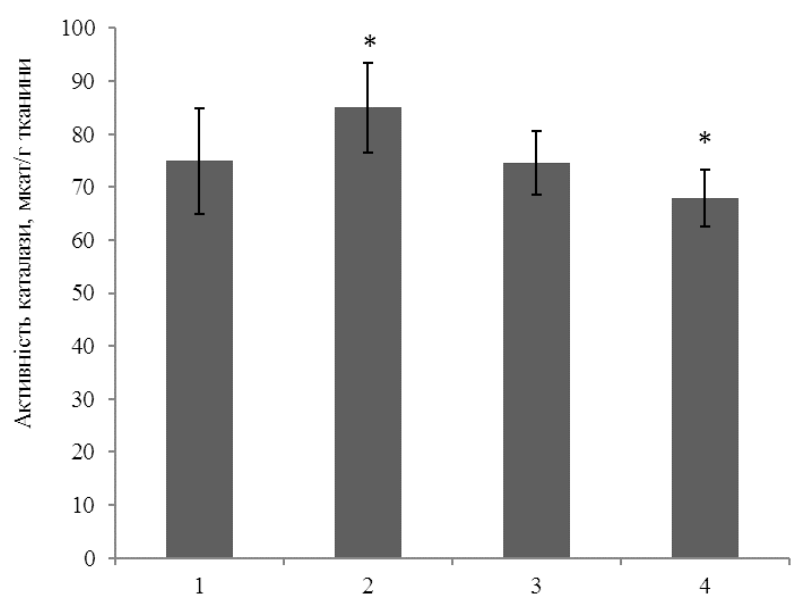

Рис. 4. Активність каталази в мітохондріальній фракції печінки піщанок: назви груп див. рис. 1

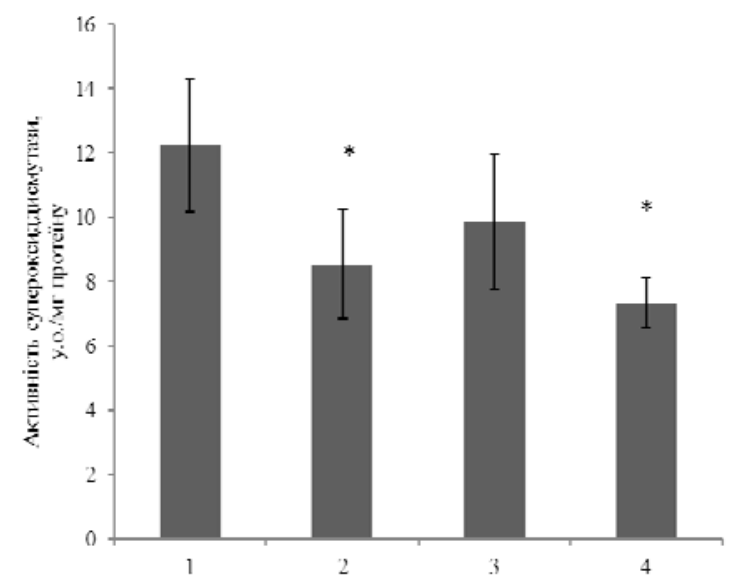

Рис. 5. Активність супероксиддисмутази в мітохондріальній фракції печінки піщанок: назви груп див. рис. 1

За результатами дослідження проведено кореляційний аналіз і розраховано кореляційний коефіцієнт Пірсона (табл.). Установлено сильний прямий зв'язок високого ступеня значимості між кількістю ТБК-активних продуктів і активністю каталази $(\mathrm{r}=0,98, \mathrm{P}<0,001)$, кількістю ТБК-активних продуктів та кількістю цитохрому $\mathrm{C}(\mathrm{r}=0,98, \mathrm{P}<0,001)$, активністю СОД і кількістю цитохрому $\mathrm{C}(\mathrm{r}=0,74, \mathrm{P}<0,01)$ за застосування Гуміліду та аскорбінової кислоти, а також між активністю СОД і кількістю цитохрому $\mathrm{C}(\mathrm{r}=0,78, \mathrm{P}<0,01)$ у разі застосування Гуміліду. Вірогідний сильний обернений зв'язок високого ступеня значимості встановлено між кількістю ТБКактивних продуктів і активністю каталази $(\mathrm{r}=-0,84, \mathrm{P}<0,01)$, активністю СОД і кількістю цитохрому $\mathrm{C}(\mathrm{r}=-0,92, \mathrm{P}<0,001)$ під час застосування препарату «Еко-імпульс Animal».

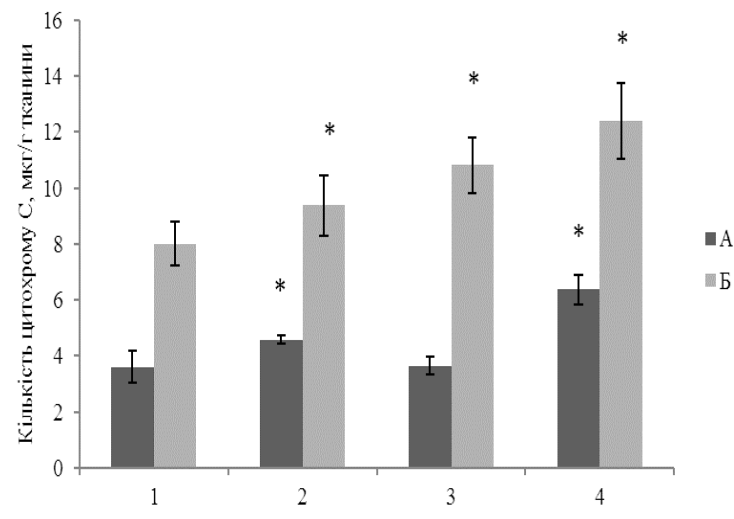

Рис. 6. Кількість цитохрому С у водорозчинній $(A)$ та мітохондріальній $(Б)$ фракціях печінки піщанок: назви груп див. рис. 1

Таблиця

Кореляційний коефіцієнт Пірсона між дослідними параметрами антиоксидантного захисту мітохондрій печінки піщанок

\begin{tabular}{|c|c|c|c|}
\hline Групи & Гумілід & $\begin{array}{c}\text { Гумілід + } \\
\text { аскорбінова } \\
\text { кислота }\end{array}$ & $\begin{array}{l}\text { «Кко-імпульс } \\
\text { Animal» }\end{array}$ \\
\hline ТБК-активні продукти -КТ & $-0,599 *$ & $0,988^{* * *}$ & $-0,842 * * *$ \\
\hline ТБК-активні продукти - СОД & 0,229 & $0,639 *$ & $-0,290$ \\
\hline ТБК-активні продукти - цитохром С & $0,496^{*}$ & $0,982 * * *$ & 0,124 \\
\hline СОД-цитохром С & $0,786^{* *}$ & $0,744 * *$ & $-0,924 * * *$ \\
\hline СОД-КТ & 0,070 & $0,534 *$ & $-0,272$ \\
\hline
\end{tabular}

Установлено помірний прямий зв'язок між кількістю ТБКактивних продуктів та кількістю цитохрому $\mathrm{C}(\mathrm{r}=0,49, \mathrm{P}<$ $0,05)$ під час застосування Гуміліду, а також між кількістю ТБК-активних продуктів та активністю СОД $(\mathrm{r}=0,63, \mathrm{P}<0,05)$ за умов застосування Гуміліду та аскорбінової кислоти. Для кількості ТБК-активних продуктів і активності каталази визначено помірний обернений зв'язок $(\mathrm{r}=-0,59, \mathrm{P}<0,05)$.

\section{Обговорення}

Дослідження загального вмісту протеїнів у отриманих мітохондріальних фракціях піщанок показали стабільний пул протеїнів за умов застосування гумінових препаратів протягом 24 діб у визначеній дозі. Однак у тварин, яких випоювали препаратом «Еко-імпульс Animal», кількість протеїнів у цій фракції вірогідно знижувалась порівняно 3 контрольною групою та іншими дослідними групами. Зниження вмісту протеїнів за впливу «Еко-імпульс Animal» може бути наслідком посилення протеолізу або гальмування біосинтезу нових протеїнів. 3 іншого боку, можливо, таке явище пов'язане з високою концентрацією вільних низькомолекулярних похідних гумінових речовин у складі даного препарату, які можуть виявляти властивості модуляторів біосинтетичних процесів.

Оцінювання ензиматичної активності аспартатамінотрансферази в мітохондріальних фракціях, отриманих із печінки дослідних тварин, показало несуттєве підвищення активності цього ензиму за впливу Гуміліду. У той же час, у тварин, яким у питну воду додавали суміш Гуміліду та аскорбінової кислоти або «Еко-імпульс Animal», активність АсАТ достовірно підвищувалась порівняно з контрольною групою. Можливо, за умов застосування даних речовин відбувається посилення процесів малатаспартатного човникового механізму, який забезпечує субстратами дихальний ланцюг і бере участь у транспорті електронів крізь мітохондріальну мембрану. Ці процеси спряжені із синтезом АТФ і енергозабезпеченням клітин печінки.

Маркери ступеня оксидативного стресу та стану антиоксидантної системи (у тому числі мітохондрій) - кількість ТБК- 
активних сполук, активність каталази та супероксиддисмутази. Суттєве зменшення кількості ТБК-активних сполук у мітохондріальній фракції печінки всіх дослідних груп тварин вказує на потужні антиоксидантні властивості гумінових речовин у складі дослідних препаратів і можливу здатність активізувати ензими антиоксидантного захисту, які знижують кількість окиснених продуктів у клітині. Активність каталази підвищувалась під час додавання до питної води Гуміліду, тоді як в інших групах перебувала в межах контрольної групи. Таке підвищення активності каталази може бути позитивною ознакою гальмування процесів утворення окисних продуктів і активізації адаптивних процесів за умов ксенобіотичного впливу, що також показано іншими авторами (Lapointe and Hekimi, 2010; Stepchenko, 2011; Paronik et al., 2015; Dai et al., 2017) та дослідженнями впливу гумінових препаратів на печінку (Serova et al., 2016). Залишається відкритим питання про специфічність дії різних форм гумінових сполук на вказаний ензим.

Зниження активності супероксиддисмутази в мітохондріальній фракції печінки під час випоювання тварин препаратом «Еко-імпульс Animal» порівняно 3 контрольною групою тварин, скоріше за все, пов'язане зі значним зниженням концентрації гідроперекису в цій групі тварин, що також свідчить про зниження оксидації мітохондрій печінки за рахунок активізації інших ланок антиоксидантного захисту, таких як цитохром C, концентрація якого збільшується в усіх експериментальних групах. Окиснена форма (цитохром $\mathrm{C} \mathrm{Fe}^{3+}$ ) виявляє потужні антиоксидантні властивості за рахунок ефективнішого, ніж СОД, окиснення супероксиданіона в молекулярний оксиген.

Завдяки особливостям будови гумінових речовин, препарати на їх основі виявляють антиоксидантну дію, знижуючи кількість окиснених продуктів у клітині (Stepchenko and Skorik, 2006; Stepchenko, 2011; Paronik et al., 2015), у тому числі, субстратів СОД, що спричинює зниження іiі активності. У літературі наведено докази гормоноподібної дії метаболітів гумінових кислот у печінці свійських тварин (Stepchenko, 2011). Метаболізм гумінових речовин у печінці супроводжується утворенням біологічно активних гумінових похідних (або самих гумінових кислот), які можуть прямо або опосередковано брати участь у регуляції біосинтезу протеїнів.

Отримані нами результати свідчать про посилення процесу біосинтезу цитохрому С (особливо за присутності аскорбінової кислоти, яка бере участь у метаболізмі феруму), який, у свою чергу, $є$ учасником дихального ланцюга мітохондрій та завдяки утворенню комплексу 3 кардіоліпіном забезпечує цілісність внутрішньої мембрани мітохондрій. Також цитохром $\mathrm{C}$ - регулятор апоптозу клітини. Отримані дані вказують на стимуляцію власних клітинних антиоксидантних систем печінки, що підтверджується підвищенням активності каталази у клітинах печінки та зниженням кількості ТБК-активних продуктів у всіх дослідних групах тварин. Можливе посилення процесу поглинання оксигену під час вживання екзогенних речовин гумінової природи $\mathrm{Ta}$, як наслідок, енергетичного забезпечення клітин за рахунок активації транспорту електронів у дихальному ланцюзі мітохондрій і спряженого з ним окисного фосфорилювання, безпосереднім учасником чого виступає цитохром С. Отримані результати збігаються із даними щодо підвищення активності аспартатамінотрансферази як активного учасника малат-аспартатного човникового трансферу, як субстратів, так і електронів у мембрані мітохондрій.

\section{Висновки}

Біологічно активні добавки гумінової природи виявляють виражений позитивний вплив на стан та функціональну активність мітохондрій печінки піщанок за рахунок підвищення антиоксидантного захисту клітин шляхом посилення адаптаційних процесів, що супроводжуються збільшенням активності каталази, аспартатамінотрансферази, кількості цитохрому С. 3'ясовано потенціювальний синергізм аскорбінової кислоти та
Гуміліду. Додавання аскорбінової кислоти до розчину Гуміліду посилює його антиоксидантні властивості.

Вживання гумінових препаратів у дозі $1 \%$ діючої речовини у питній воді протягом 24 діб не викликало інтоксикації в мітохондріях печінки, що дозволяє рекомендувати ці біологічно активні добавки до подальших досліджень із метою їх упровадження в медичну практику.

\section{References}

Adrianova, I. G. \& Sidorova, N. D. (1990). Citohrom C i ego rol' v processah tkanevogo dyhanija. Citohrom $\mathrm{C}$ i ego klinicheskoe primenenie [Cytochro$\mathrm{me} \mathrm{C}$ and its role in the processes of tissue respiration. Cytochrome $\mathrm{C}$ and its clinical application]. Leningrad University Press, Leningrad (in Russian).

Andreeva, L. Y., Kozhemjakyn, L. A., \& Kyshkun, A. A. (1988). Modyfykacyja metoda opredelenyja perekysej lypydov $\mathrm{v}$ teste $\mathrm{s}$ tyobarbyturovoj kyslotoj [Modification of the method for the determination of lipid peroxides in the test with thiobarbituric acid]. Laboratory Work, 2, 41-43 (in Russian).

Begriche, K., Massart, J., Robin, M.-A., \& Borgne-Sanchez, A. (2011). Drug-induced toxicity on mitochondria and lipid metabolism: Mechanistic diversity and deleterious consequences for the liver. Bernard Fromenty Journal of Hepatology, 54(4), 773-794.

Birk, A. V., Chao, W. M., Bracken, C., Warren, J. D., \& Szeto, H. H. (2014) Targeting mitochondrial cardiolipin and the cytochrome c/cardiolipin complex to promote electron transport and optimize mitochondrial ATP synthesis. British Journal of Pharmacology, 171(8), 2017-2028.

Brinkmann, C. R., Jensen, L., Dagnaes-Hansen, F., Holm, I. E., Endo, Y., Fujita, T., Thiel, S., Jensenius, J. C., \& Degn, S. E. (2013). Mitochondria and the lectin pathway of complement. The Journal of Biological Chemistry, 288(12), 8016-8027.

Buron, N., Porceddu, M., Roussel, C., Begriche, K., Trak-Smayra, V., Gicquel, T., Fromenty, B., \& Borgne-Sanchez, A. (2017). Chronic and low exposure to a pharmaceutical cocktail induces mitochondrial dysfunction in liver and hyperglycemia: Differential responses between lean and obese mice. Environmental Toxicology, 32, 1375-1389.

Burtis, C., Ashvud, E., \& Bruns, D. (2012). Tietz textbook of clinical chemistry and molecular diagnostics, 5 th ed. Saunders.

Cui, H., Kong, Y., \& Zhang, H. (2012). Oxidative stress, mitochondrial dysfunction, and aging. Journal of Signal Transduction, 646-654.

Dai, D. F., Chiao, Y. A., Martin, G. M., Marcinek, D. J., Basisty, N., Quarles, E. K., \& Rabinovitch, P. S. (2017). Chapter seven mitochondrial targeted catalase: Extended longevity and the roles in various disease models. Progress in Molecular Biology and Translational Science, 146, 203-241.

Donghong, L., Lei, L., Pengxi, L., Yi, L., \& Xiangyun, C. (2015). Apoptosis of hela cells induced by a newtargeting photosensitizer-based PDT via a mitochondrial pathway and ER stress. OncoTargets and Therapy, 8, 703-711.

Dykens, J. A., Marroquin, L. D., \& Will, Y. (2007). Strategies to reduce late-stage drug attrition due to mitochondrial toxicity. Expert Review of Molecular Diagnostics, 7, 161-175.

Felser, A., Stoller, A., Morand, R., Schnell, D., Donzelli, M., Terracciano, L., Bouitbir, J., \& Krähenbühl, S. (2014). Hepatic toxicity of dronedarone in mice: Role of mitochondrial $\beta$-oxidation, Toxicology, 323, 1-9.

Gergalova, G. L., \& Skok, M. V. (2011). Vplyv nikotynu na membrannyj potencial mitohondrij: Uchast' nikotynovyh acetylholinovyh receptoriv [The influence of nicotine on the mitochondrial membrane potential, participate nicotinic acetylcholine receptor]. The Ukrainian Biochemical Journal, 83(5), 13-21 (in Ukrainian).

Hamdallah, A., Davydov, V. V., \& Shvets, V. N. (2014). Oxidative stress and the enzyme system of aldehyde catabolism in the muscle mitochondria of immobilized pubertal rats. Ukrainian Biochemical Journal, 86(6), 50-55 (in Ukrainian).

Hynes, J., Nadanaciva, S., Swiss, R., Carey, C., Kirwan, S., \& Will, Y. (2013). A high-throughput dual parameter assay for assessing druginduced mitochondrial dysfunction provides additional predictivity over two established mitochondrial toxicity assays. Toxicology in Vitro, 27(2), 560-569.

Koroljuk, M. A., Yvanova, L. Y., Majorova, Y. G., \& Tokareva, V. E. (1988). Metod opredelenyja aktyvnosty katalazy [Method for the determination of catalase activity]. Laboratory Work, 1, 16-19 (in Russian).

Kostjuk, V. A., Potapovych, A. Y., \& Kovaleva, Z. V. (1990). Prostoj i chuvstvitel'nyj metod opredelenija aktivnosti superoksiddismutazy, osnovannyj na reakcii okislenija kvercetina [A simple and sensitive method for determining the activity of superoxide dismutase, based on the oxidation reaction of quercetin]. Questions of Medical Chemistry, 36, 2, 88-91 (in Russian).

Labbe, G., Pessayre, D., \& Fromenty, B. (2008). Drug-induced liver injury through mitochondrial dysfunction: mechanisms and detection during preclinical safety studies. Fundamental and Clinical Pharmacology, 22, 335-353. 
Lapointe, J. (2014). Mitochondria as promising targets for nutritional interventions aiming to improve performance and longevity of sows. Journal of Animal Physiology and Animal Nutrition, 98(5), 809-821.

Lapointe, J., Hughes, B. G., Bigras, E., \& Hekimi, S. (2014). Compensatory elevation of voluntary activity in mouse mutants with impaired mitochondrial energy metabolism. Physiological Reports, 2(11): e12214.

Melnichuk, S. D., Khizhnyak, S. V., Morozov, V. S., \& Voytsitsky, V. M. (2013). Aktyvnist' NAD•H-generujuchyh enzymiv ta vmist cytohromiv u mitohondrijah pechinky ta miokarda shhuriv za eksperymental'nogo gipobiozu [The activity of NAD•H-generating enzymes and content of cytochromes in the mitochondria of liver and myocardium of rats under experimental hibernation]. The Ukrainian Biochemical Journal, 85(4), 75-81 (in Ukrainian).

Pan, K., Gupta, P., Damania, P., Yadav, A. K., Gupta, A., Ashraf, A., \& Venugopal, S. K. (2016). Mineral pitch induces apoptosis and inhibits proliferation via modulating reactive oxygen species in hepatic cancer cells. BMC Complementary and Alternative Medicine. 16, 148.

Paronik, V. A., Stepchenko, L. M., Djachenko, L. M., Ljevyh, A. E., \& Shevcova A. I. (2015). Vplyv korvitynu ta gumilidu na stan oksydantno-antyoksydantnoi' systemy shhuriv na foni vvedennja adrenalinu [Impact of corvitin and humilid on the state of the oxidant-antioxidant system of rats on the background of the introduction of adrenaline]. Biologija Tvaryn, 17(4), 109 114 (in Ukrainian).

Ryzhkovskaia, E. L., Verigo, N. S., Kuznetsova, T. E., \& Ulashchik, V. S. (2014) The ultrastructural organization of the liver of rats with experimental hepatitis after drinking mineral water containing humic acids. Voprosy Kurortologii, Fizioterapii, i Lechebnoi Fizicheskoi Kultury, 5, 35-41 (in Russian).

Selyvanov, E. A., Hmilova, G. A., Beljaeva, Y. S., Slepneva, L. V., \& Sydorova, N. D. (1997). Sposob kolichestvennogo opredelenija citohroma C y preparatah, soderzhashhih kollagen [Method of quantitative determination of cytochrome $\mathrm{C}$ in preparations containing collagen]. Patent of Russian Federation № 2084869, G01N21/25, application number 94023438/25 (in Russian).
Serova, D., Taran, O., \& Dyomshina, O. (2016). Biologichna aktyvnist' preparativ na osnovi guminovyh rechovyn u pechinci pishhanok (Meriones unguiculatus) [Biological activity of humic substances in the liver of Mongolian gerbils (Meriones unguiculatus)]. Visnyk of Dnipropetrovsk University. Biology, Ecology, 24(2), 410-415 (in Ukrainian).

Stepchenko, L. M. \& Skorik, M. V. (2006). Stan systemy antyoksydantnogo zahystu erytrocytiv kurej-nesuchek za dii' guminovyh rechovyn [System status of erythrocyte antioxidant protection of laying hens under the influence of humic substance]. Scientific Bulletin of Lviv National University of Veterinary Medicine and Biotechnology S. Z. Gzhytsky, 7(3-4), 137-143 (in Ukrainian).

Stepchenko, L. M. (2010). Znachenia katepsinu B ta jogo inhibitoriv v reguljaciji obminnyh procesiv u kurchat-brojleriv za diji rechovyn guminovoji prypody [The value of cathepsin B and its inhibitors in the regulation of metabolism in broiler chickens for the actions of humic substances]. Biologija Tvaryn, 12(2), 180-188 (in Ukrainian).

Surai, P. F., \& Fisinin, V. I. (2013). Natural antioxidants in hen's embryogenesis and antioxidant defence in postnatal development. Agricultural Biology, 2,3-17.

Szabó, J., Vucskits, A. V., Berta, E., Andrásofszky, E., Bersényi, A., \& Hullár, I. (2017). Effect of fulvic and humic acids on iron and manganese homeostasis in rats. Acta Veterinaria Hungarica, 65(1), 66-80.

Vadzyuk, O. B., Mazur, Y. Y., \& Kosterin, S. O. (2011). Reguljacija funkcionuvannja ATR-chutlyvogo $\mathrm{K}^{+}$-kanalu mitohondrij miometrija aktyvnymy formamy kysnju [Regulation functioning of ATP-sensitive $\mathrm{K}^{+}$-channels myometrium mitochondrial reactive oxygen species]. Ukrainian Biochemical Journal, 83(3), 48-57 (in Ukrainian).

Wieckowski, M. R., Giorgi, C., Lebiedzinska, M., Duszynski, J., \& Pinton, P. (2009). Isolation of mitochondria-associated membranes and mitochondria from animal tissues and cells. Nature Protocols, 4(11), 1582-1590.

Young, D. S. (2014). Effects on clinical laboratory tests: Drugs, disease, herbs and natural products. American Association for Clinical Chemistry. 